\title{
Student's Understandings and Practices Regarding Communicative Language Teaching (CLT) in Malaysian Secondary Schools
}

\author{
Reza Raissi \\ Faizah Mohamad Nor \\ Marzilah A Aziz \\ Zaidah Zainal \\ Zanariah Md Saleh \\ Language academy
}

Universiti Teknologi Malaysia, 81310 Skudai, Johor, Malaysia Corresponding authorReza Raissi: raissi_reza@yahoo.com

\section{Doi: 10.5901/mjss.2013.v4n4p325}

\section{Abstract}

\begin{abstract}
Nowadays in most of the educational systems all over the world many curriculum designers as well as administrators in the ministry of education of different countries recommended a very well-known approach of language teaching and learning namely Communicative Language Teaching (CLT) in the English classes. In such a circumstance that CLT has been widely adopted by textbook designers and material writers all over the world, especially in ESL countries, different researches which have been conducted in the ESL/EFL countries shows that still in many cases teachers and students have different challenges and problems in order to apply CLT in their schools. In this study researchers attempted to investigate how CLT understood and implemented in Malaysian secondary schools from the students' point of view. In order to get a clear picture of students' understanding, perceptions and the way that they incorporate CLT in the secondary schools a semi-structured interview was conducted among 30 ESL Malaysian students in Malaysian secondary schools. Results of the study showed different contextual and cultural problems regarding implementation of CLT from the students' viewpoint. There were some mismatches between what is going on in Malaysian secondary schools English classes and what has been assigned to do by the curriculum of the ministry of education of this country. At the end of the study some pedagogical implications have been proposed by the researchers which can help decision makers in the language teaching and learning of this country.
\end{abstract}

Keywords: Communicative language teaching, English ESL learners, English language teaching \& learning.

\section{Introduction}

Communicative Language Teaching (CLT) has been introduced to ESL contexts since 1970's. According to some researchers in CLT students and teachers should mainly focus on meaning rather than form (Hymes, 1971; Wilkins, 1976; Widdowson, (1978). Based on the Hymes view (1971) main role and function of the language in the CLT classes relates to communication, in this view special attention has been given to meaning and communication through learning the language by authentic tasks related to real world contexts. According to Xia (2006) CLT has been recognized as an ideal approach in teaching and learning of the second/foreign language and many new textbooks have been designed based on CLT's functional view of the language.

Although many scientists, scholars and teachers expressed their favorable attitude regarding CLT but it does not mean that their positive attitude match with what teachers and students exactly do in the language classrooms. Parabu (1990) mentioned that most of the times a solid theory or approach is not always applicable in many special educational contexts because of several reasons like variations in social situations, different educational organizations and some challenges students and teachers may face in different countries from different level of English and L1 background or school facilities.

In earlier version of CLT namely Functional-notional approach main focus of importance was on functional notional syllabus, in which syllabus designers had authority to integrate the core goals of the approach to design a learner centered environment in class in which students could learn the language through communication. In this approach the functional view of the language emphasized as an essential for organizing foreign language curriculum and grammar is 
only taught during real life situations and authentic tasks (Wilkins 1972; 1976, Canale and Swain 1980). According to Yoon (2004) learning a language cannot implemented through teaching and learning synthetic units like grammar, functions or notions without pushing learners to use the language in authentic contexts.

CLT is the focus of this study for several reasons, first reason relates to the fact that CLT is an offspring of learnercentered language teaching movements in which the role of the teacher is as a facilitator or coach who push the students to communicate in English and improve their language through using authentic tasks. This goal aligns with the assigned curriculum by ministry of education of Malaysia (KBSM). According to this curriculum all of the governmental secondary schools in Malaysia should use CLT in the secondary schools in order to improve learners' English proficiency through the classroom interactions. Second reason relates to the nature of CLT in which this approach mainly focuses improving learners' communicative competence, this goal of CLT aligns with the expectations of English teachers and English learners in Malaysia in which they try their best to push students in order to have good command of English in the global village.

According to the Wikipedia the free internet encyclopedia Malaysia ranked as the ninth touristy country all over the world, it goes without saying students in this country should have good command of English to communicate with the foreigners as easily as possible. On the other hand they need English proficiency for their future educational career as well as using internet for different purposes. Third and last reason to conduct this study among Malaysian ESL learners is that as researchers surfed on the net they didn't find many studies regarding students' perceptions about CLT. In fact most of the studies which have been done in different countries related to teachers' perceptions and challenges. Students as the main role makers in the learner-centered classes play crucial role in CLT classes and it seems crystal clear that their attitudes, perceptions and challenges in applying CLT can help researchers to know their tentative problems to be reflected and therefore their curriculum could be revised and they can help to administrative executors, curriculum designers and material writers to improve English programs in Malaysia by reflecting their ideas.

\section{Literature review}

Dam (2001), emphasized on the fact that GTM may be considered as an effective language teaching for learning grammatical forms, but this approach has been criticized for its main shortcoming which relates to the point that, this method turns students to passive receivers of the grammatical rules and this method also ignores importance of using the target language in the English teaching classes. According to Rao, (1996) after several years of language learning most of the students who have been trained by old language teaching approaches may have a good competence in grammatical competence and they can easily translate from the target language to their mother tongue but they cannot speak the target language fluently. These kinds of students cannot understand what exactly native speakers say and they cannot communicate with them easily too.

Nowadays most of the scholars all around the world changed the name of the world to the global village by increasing the usage of internet in almost all of the countries. Grammar Translation Method (GTM) and other old language teaching methods mainly focus on reading and writing and they do no pay enough attention to speaking and listening. Communicative Language Teaching (CLT) is a language teaching approach which mainly focuses on communicative competence of the learners and considers communicative competence as the goal of language teaching and learning. Brown (2001), mentioned some guidelines for CLT teaching: teaching purposes mainly concerned on all of the communicative competence not only focusing on linguistic competence like GTM, this approach has been designed in a way that forcing students to use language to improve their communicative competence in an authentic and real life situation context. According to this approach the importance of fluency seems more than the accuracy to push students communicating in a real life situation context. In the communicative based classes students are engaged to use the language productively and receptively in a stress free situation (p. 266). As it seems clear from the characteristics of CLT, this approach mainly focuses on fluency rather than accuracy. As it has been discussed earlier fluency based approaches seems essential for the English learners, especially for those who are studying English for the immigration purposes, such as people who want to immigrate for Masters and PhD purposes. And also many scholars have to participate in different international conferences which may be held in English and need a good command of English competence.

Karavas-Doukas (1995) mentioned the main reason of the CLT implementation problems relates to the teachers perception regarding the CLT principles. Teachers' perception mainly shows what they think about language teaching so it seems very important to know what they really know and think about CLT principles and what they apply in their classrooms. Littlewood(1981) mentioned that CLT principles may contradict with the existing precipitin of language teaching in many contexts. In order to apply CLT in EFL or ESL contexts teachers should adopt their perceptions regarding the CLT approach. Brumfit (1985) believes that communication system in foreign/second language is not a 
solid system to be learned by the English learners or taught by teachers but it is a task which should be implemented in classrooms. By considering this point in mind variety of teaching techniques, teaching methods, curriculum and materials can be designed. Richard \& Rodgers (1985) stated that CLT should be considered as an approach rather than a method, according their view in this approach there is a neat distinction between the theory of language and what is going on in the implementation process, in which implementation process directly relates to teachers and students' perception of this approach and variations in applying this approach in different classes according to their specialized context.

\section{Method}

\subsection{Research design}

In this study researchers used qualitative method of data collection in order to collect data from the respondents. To this aim researchers used semi-structured interviews in order to elicit students' attitudes and problems regarding the implementation of CLT which has been assigned to implementing all Malaysian governmental secondary schools. Participants of this study were 30 secondary students in Pasirgudang district, Johor, Malaysia. They have studied in form one to form four levels, and their age rang was between 13 to 16 years old. In this study researchers used stratified purposeful sampling technique in order to select their participants to this aim they had different criteria in their mind to choose their required sample, the first and most important factor related to the school types, researchers chose governmental schools which follow the assigned curriculum by the ministry of education of Malaysia. Second criterion related to the level of the schools in which researchers chose just secondary schools that students are more proficient to implement CLT in classes in comparison to primary schools. Third criterion related to the setting of the schools which should be located in Johor Bahru that researchers could do their data collection there and generalize the findings to the whole schools of Malaysia.

\subsection{Interview protocol}

In this research, researchers used semi-structure interview in order to find out different problems and challenges of the students regarding CLT implementation in Malaysian secondary schools. To this aim a three phase semi-structured interview has been designed.

In the first phase of the interviews researchers asked students' ideas and perceptions about the implementation of CLT in Malaysian secondary schools whether they have favorable or unfavorable attitude regarding CLT and their tentative challenges (if any) regarding CLT use in classes. Also researchers asked participants ideas about the negotiations of teacher and learners in the class to see whether these kinds of negotiations can help them to improve their communicative competence or not.

In the second phase of the interviews researchers asked students about the quality of the textbooks and other supplementary materials (if any) their teachers use in the classes, and their overall opinion about the English curriculum in Malaysia. In order to complete the second phase questions researchers asked students' about the amount of real-life situation and authentic tasks in the classes and whether they found it useful for their pedagogical purposes or not.

In the third part of the interviews researchers asked students about the process of learning different skills in the Malaysian secondary schools. Researchers asked students' feeling about their improvement in different skills (reading, writing, speaking \&listening) through CLT, and their ideas about the error correction in CLT method; how they want teachers to feedback on their errors (implicitly or explicitly) when their teachers want to teach them different skills.

\section{Results \& discussion}

\subsection{Results of the first phase of the study}

In the first phase of the current study firstly researchers asked students' favorable or unfavorable attitudes regarding the nature of CLT in Malaysian secondary schools, in the following table you can see frequency and percentage of students' opinions regarding the nature of $C L T$. 
Table 1 student's perceptions regarding the nature of CLT

\begin{tabular}{|ll|c|c|c|c|}
\hline & Frequency & Percent & Valid Percent & Cumulative Percent \\
\hline \multirow{3}{*}{ Valid } & favorable & 25 & 83.3 & 83.3 & 83.3 \\
& unfavorable & 5 & 16.7 & 16.7 & 100.0 \\
& Total & 30 & 100.0 & 100.0 & \\
\hline
\end{tabular}

As it seems clear from the above table most of the students (83.3\%) showed favorable attitudes regarding the nature of CLT and implementation of CLT in Malaysian secondary schools. Then researchers tried to find out the reasons that some of the participants reflected unfavorable attitudes regarding CLT. Participants who were not agree with the CLT principles mentioned that they had some problems regarding the implementation of CLT in Malaysian secondary school classes, such as problems of different L1 languages which affected students' performance in the ESL classes. As Malaysia is a multicultural society with three different races namely Malay, Chinese and Indian, participants believed that, those students with different language backgrounds could not speak with each other in the target language easily. Another problem which has been mentioned regarding CLT implementation in Malaysia related to the schools' facilities as they have mentioned it seems difficult to apply CLT in classes with low facilities, while CLT needs high facilities to be implemented in Malaysian secondary schools. But most of the participants showed favorable attitudes regarding the CLT implementation in Malaysian secondary schools and they found CLT appropriate for their pedagogical purposes.

\subsection{Results of the second part of interview}

In this section researchers asked students' ideas about the English textbooks, assigned curriculum by the ministry of education, and amount of using authentic tasks \& facilities in the Malaysian secondary schools results of the study follows in this section.

English language learners in the Malaysian secondary schools mentioned that in most of the items textbooks are satisfactory and they paid enough attention to main four skills but they had problems regarding some sub skills like grammar and pronunciation and vocabulary. Most of the students believed that although teachers use supplementary materials to teach some sub-skills to them but the quality of the supplementary materials were not good and they could not improve different sub-skills of the language learners.

In other section of the second phase of interview researchers asked students about another principle of CLT namely creating authentic real life situation for the learners by the teachers. Most of ESL learners mentioned that usually they have enough authentic tasks in the schools. They mentioned that the amount of the group work and class discussions were satisfactory. They mentioned that school principals organize 2 or 3 days English campuses for 3 times in an academic year in some beautiful sites like Desaru Beach, Johor, Malaysia. It goes without saying that organizing these kinds of activities outside of the classroom can create authentic context for the students in order to express themselves in English and it can improve outgoing personality of the students as well. But some of the students complained about the school facilities and they have mentioned that although they have language lab in their schools but most of the times they could not use the language labs because of the shortage of the classes in their schools and they mentioned that although their schools have video projector \& CD players but they don't have enough laptops to support class activities and teachers should bring their own laptops.

\subsection{Results of the third part of the study}

In the third phase of the study researchers asked students about the process of learning different skills and sub-skills in the Malaysian secondary schools in order to see whether CLT method was effective for them and their pedagogical purposes or not. On the other hand researchers attempted to investigate about participants ideas regarding error correction \& grammar teaching to see whether they prefer that their errors to be corrected explicitly or implicitly, or grammar principles to be taught implicitly or explicitly. Most of the students mentioned that by incorporating CLT in the language classes their receptive skills (listening \& reading) have been improved while they have mentioned their productive skills stills (writing \& speaking) still didn't improve too much. They have mentioned that in the Malaysian secondary schools most of the teachers usually focus on receptive skills and they do not pay enough attention to the productive needs of the students. According to their viewpoint in Malaysian secondary schools most of the teachers spend big amount of the class time on the reading skill, it seems crystal clear that when they are not speak a lot in the 
classroom atmosphere they cannot speak outside of the classroom and they can express themselves in English in other contexts too. Another problem related to the lack of peer-review writing tasks in the secondary schools, students mentioned that they do not practice writing in pair groups to a high extent and no enough attention paid to writing. But most of them were satisfied with the quality of teaching listening and reading skills.

In the last part of the data collection researchers asked students about some sub-skills and the way they could be presented in the language classrooms. Most of the students mentioned they are eager to receive grammar, pronunciation and vocabulary by explicit instruction type rather implicit type. They have mentioned that by explicit instruction the structure of the sentence, syntax, vocabulary and pronunciation they can learn much easier than the implicit instruction. In addition they have mentioned that they were agreed with the explicit error corrections in the class which is in contradiction with CLT principles.

\section{Conclusion \& pedagogical implications}

According to the assigned curriculum by the ministry of education of Malaysia all of the Malaysian governmental secondary schools should use CLT approach in their classes. If you surf on the net or by reviewing on different journals you can find out not enough studies have been conducted regarding students' perceptions and challenges about CLT. Researchers wanted to investigate students' challenges and problems regarding the implementation of CLT in Malaysian secondary schools as the main role makers in the general English classes. As it has been discussed before, most of the students showed favorable attitudes regarding the CLT principles. But they have mentioned that implementation of CLT should be adapted to the Malaysian context. For example most of them believed that errors should not be fossilized in the learners' minds and should be detected by the teacher immediately. Another important thing that they have reflected related to grammar instruction and they believed that teaching grammar by old language teaching methods like Grammar Translation Method (GTM) or teaching explicitly rather implicitly can help them to learn language grammatical and syntax items better. In short we can conclude from the above discussion that by combining some techniques from old language teaching methods like GTM with CLT principles we can have an appropriate and ideal method of language teaching in Malaysian secondary schools.

Hopefully the results of the study is useful for a number of people and they can benefit from the results of the current study, first executive administrates in the ministry of education of Malaysia to use the results of the current study to improve the assigned curriculum to the Malaysian secondary schools, second textbook designers to us findings of this study to improve Malaysian secondary schools textbooks, and finally students who could express their ideas regarding CLT and its implementation in Malaysia.

\section{Acknowledgments}

Researchers are very thankful to the participants of the study who have cooperated with researchers kindly.

\section{References}

Brown, H. D. (2001). Teaching by principles: An interactive approach to language pedagogy (2nd ed.). Englewood Cliffs, NJ: Prentice Hall Regents.

Brumfit, C.J. (1985). Langgge and Literature teaching From practice toprinciple. Oxford Pergamon Press.

Canale, M., \& Swain, M. (1980). Theoretical bases of communicative approaches to second language teaching and testing. Applied Linguistics, 1, 1-47.

Dam, P. (2001). Hindsight of an English language learner. Paper presented at the Annual

Meeting of the Texas Education Agency's 64th Annual Conference for Diverse Learners

in Secondary Schools. Texas Austin.

Hymes, D. (1971). Competence and performance in linguistic theory. In R. Huxley \& E.

Ingram (Eds.), Language acquisition: Models and methods (pp. 3-28). London:Academic Press.

Karavas-Doukas, E. (1996). Using attitude scales to investigate teachers' attitudes to the

communicative approach. ELT Journal, 50, 187-198.

Littlewood, W. T. (1981). Communicative language teaching: An introduction. Cambridge: Cambridge University Press.

Prabhu, N. S. (1990). There is no best method-Why? TESOL Quarterly, 24(2), 161-176.

Rao, Z. (1996). Reconciling communicative approaches to the teaching of English with traditional Chinese methods.Research in the Teaching of English, 30(4), 458-471.

Richards, J. C., \& Rodgers, T. S. (1986). Approaches and methods in language teaching.Cambridge: Cambridge University Press.

Widdowson, H. G. (1978). Teaching Language as Communication. Oxford: Oxford University Press. 
Wilkins, D.A. (1972). Linguistics and Language Teaching. London: Edward Arnold.

Wilkins, D. A. (1976). Notional Syllabus. Oxford, Oxford University Press.

Xiao-xia, Q. (2006). Form-focused instruction in a communicative language classroom.Sino-US English Teaching, 3(12), 21-27.

Yoon, K. (2004). CLT theories and practices in EFL curricula: A case study of Korea[Electronic version]. Asian EFL Journal, 6(3).1-16. 